\title{
An Experimental Approach to Transdisciplinary Methodology in Housing
}

\author{
Esen Gökçe Özdamar
}

\begin{abstract}
This article explores a transdisciplinary research method derived from the need to determine the tacit knowledge in the re-reading of contemporary housing patterns in Narcity in İstanbul, Donau City in Vienna, and the Eastern Docklands in Amsterdam. The need for the development of such a method derives from two main problems: first, the necessity of re-reading the new dynamics of contemporary housing within the context of changing urban narratives in a globalised world; second, the consideration of the need for a dynamic view that engages both the subject and object in housing research. The residential areas are simultaneously evaluated at three levels defined by Basarab Nicolescu through an experimental and three-dimensional surface and inquiry space. It is projected that this methodology can help transgress the boundaries between fixed forms of policies and production and help bridge fact and fiction in re-reading and mapping controversies among researchers at different levels of comprehension.
\end{abstract}

Keywords: transdisciplinary approach, experimental, contemporary housing, tacit knowledge.

\section{Introduction}

This study is a re-reading of emerging fragments observed in contemporary housing areas located in Narcity in İstanbul, Donau City in Vienna, and the Eastern Docklands in Amsterdam through an experimental approach to transdisciplinary methodology. The housing areas transcend the boundaries posed by a case study in which the researcher approaches the phenomenon through a predetermined set of parameters. Evaluated as exemplars rather than case studies, these chosen housing areas represent unconstructed realities and potentialities in housing. Within this research, Thomas Kuhn's idea of an exemplar is used to understand to fragments of the re-reading process. According to Kuhn, an exemplar enables us to see new problems similar to the exemplar and apply analogies to those new problems (Kuhn 1962, 41).
In this context, the exemplars emerging as a topography that represents ambiguous and tacit knowledge for discovering and understanding the knowledge flow between the particular and the general rather than for testing fragments or as a representation of phenomena, are evaluated within their differentiation, which can form a paradigmatic turn.

The need for such a re-reading emerges from the phenomena of observed, perceived realities in housing areas and focuses on differences rather than similarities between them. In re-reading these contemporary housing exemplars, a transdisciplinary approach, a method defined by Basarab Nicolescu (2002) emerges. Therefore, this study emerges as a step towards understanding the relationship between methodology and contemporary housing through this approach, rather than describing a concrete approach to developing it. It is estimated that comprehending the

Stable URL: https://arcc-journal.org/index.php/arccjournal/article/view/1075 DOI 10.17831/enq:arcc.v18i1.1075

Corresponding Author: Esen Gökçe Özdamar <gokceozdamar@gmail.com>

Published by the Architectural Research Centers Consortium under the terms of the Attribution-NonCommercial-ShareAlike 4.0 International license 
close relationship between the three "levels" of this methodology can help architecture and urban studies researchers determine new and experimental patterns. The re-reading of housing exemplars is accomplished simultaneously on the three levels of transdisciplinary methodology: 1) the ontological, 2) the epistemological axiom and 3) the logic of the included middle. In comprehending the close relationship between the levels during the re-reading process, they are evaluated experimentally as a fusion of overlapping fragments of literature review, photographs, video recordings, in-depth interviews, a public survey and an art project as the logical axiom (the included middle) with "open-ended" questionnaires that gather subjective and objective data. The data collection process and interviews are not precisely planned and directed at the beginning; instead, they emerge throughout the process and in different phases of the research. This arbitrary quality structures the approach to understanding transdisciplinary methodology. Therefore, this article is not concerned with predetermining the transdisciplinary methodology before the exemplars are chosen nor applied depending on its defined axioms. Instead, methodology is revealed through the intermediate process of the research that links theory and practice.

Therefore, this study intends to determine the thresholds of this new method and experiment with it autonomously through a web-like "three-dimensional narrative inquiry space" - a term coined by Clandinin and Connelly (2000, 49)-that emerges from re-reading housing areas. This dimensional space is also multi-directional, allowing "inquiries to travel inward, outward, backward, forward and situated within space" (Clandinin and Connelly 2000, 49). The researcher is situated in the "midst-located somewhere along the dimensions of time, place, the personal, and the social" (Clandinin and Connelly $2000,63)$. The three-dimensional narrative inquiry space in this article is understood as a metaphor for dealing with ambiguous urban and housing problems within the context of the transdisciplinary approach, in which the research problem also involves timespace and the researcher/s exist within different layers and fragments. The exemplars reveal fragments, such as speed, experimentalism and flexibility, as transient fragments are explored in urban narratives that await new meanings. Speed, experimentalism and flexibility are some of the emerging dynamic fragments shaped by globalisation, housing policies in new approaches to urban housing in different contexts in İstanbul, Vienna and Amsterdam.

The nature of housing is complex because urban housing not only shapes urban life and the articulation and attachment of dwellers to their environment but also triggers new potentialities in the built space and opens up new forms of lifestyle. The narrative of contemporary housing involves numerous visible and invisible factors seen from the perspective of multiple actors, such as different dwellers, architects, urban planners, the housing production sector, policy makers, institutions, housing production and construction firms and real-estate agencies. The need to approach contemporary housing from a transdisciplinary perspective is related to understanding the deficiencies in evaluating housing today as chaotic urban life has created many fragments, which are connected by emerging relationships.

\section{TRANSDISCIPLINARY METHODOLOGY}

The roots of the term "transdisciplinary" extend back to the descriptions of the philosopher Jean Piaget, astrophysicist Erich Jantsch and mathematician Andre Lichnerowicz in the 1970s (Nicolescu 2008, 14). This methodology, named by quantum physicist Basarab Nicolescu in his book, "Manifesto of Transdisciplinarity" (Nicolescu 2002), was derived from Nicolescu's practice in quantum physics and was related to the "status of the subject" (Nicolescu 2006, 142). Nicolescu redefined transdisciplinary as "a new knowledge" area involving "science and art" in 1985. He defined this knowledge area as a fusion of disciplines rather than a metatheory, with the word "trans" meaning between, across, and beyond. Transdisciplinarity involves something that is beyond any discipline (Volckmann and Nicolescu 2007, 79, 82, 84). Therefore, transdisciplinarity was defined as "not via a new discipline, but via a new methodology" and "not with a new discipline, but with a new knowledge-knowledge about what is in between, across and beyond disciplines" (Volckmann and Nicolescu 2007, 82) (Figure 1).

Nicolescu's approach does not end multi/inter/disciplinary approaches but extends beyond them to understand the nature of the phenomenon. It is a fusion of scientific knowledge and transgresses boundaries and methods (Schneider 2011, 98). The phrase "beyond disciplines" refers to an "immense space of new knowledge" in which the outcome is "the formulation 


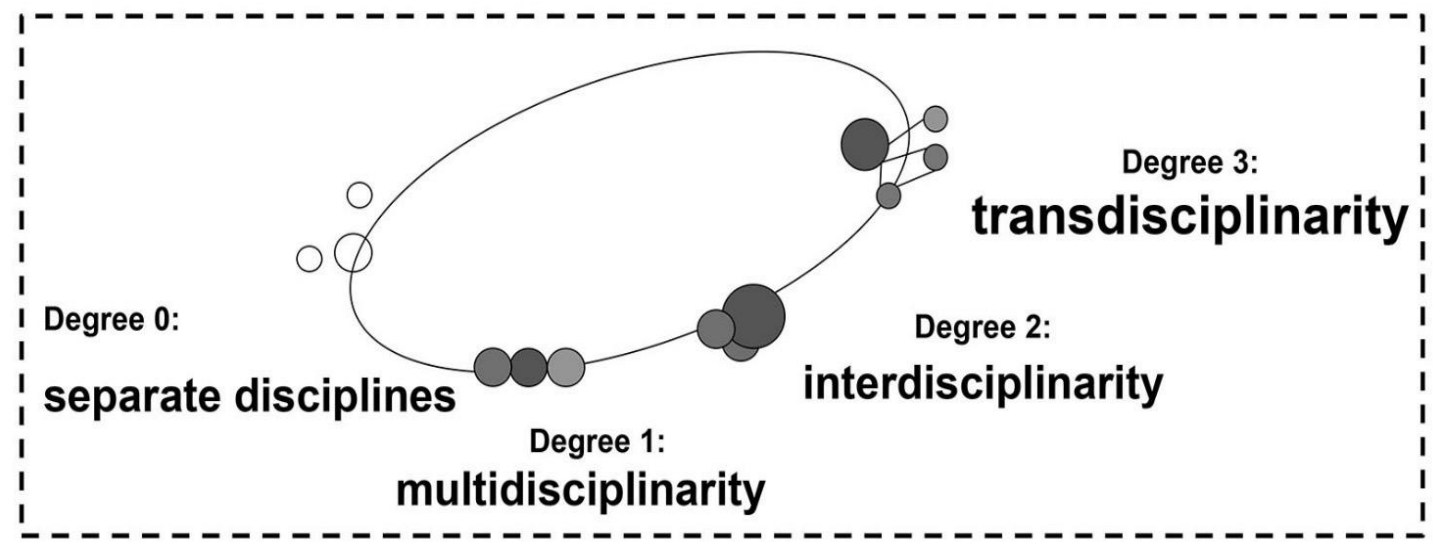

Figure 1: Relationship of disciplines (based on the explanations of Nicolescu 2002; Novak 1998, 85; Özdamar 2011).

of the methodology of transdisciplinarity" (Nicolescu $2008,15)$. There is a clear difference between disciplines. We can relate this "immense space" of the emerging knowledge discovered through this methodology as a rhizomatic, three-dimensional-indeed, even four-dimensional-space that also includes the time-embedded and heterogeneous overlapping fragments, gathered together to form a new approach to knowledge and how it is evaluated.

Nicolescu defines transdisciplinarity as a new knowledge transgressing the boundaries between the self and phenomena, connecting three axioms simultaneously and engaging them not through hierarchical levels but through an approach in which every level exists at the same time. Transdisciplinary knowledge (TK) is "a new type of knowledge-in vivo knowledge" (Nicolescu 2005, 7). This knowledge production is also referred to as Mode II knowledge, which brings with it a new way of thinking about science. In contrast to Mode I, Mode II knowledge is heterogeneous, heterarchical and transient. It is also socially accountable and reflexive (Gibbons et al. 1994, 3) (Figure 2).

According to Nicolescu, these axioms are defined as; "the ontological axiom (Reality)," "the logical axiomthe logic of the included middle," and "the

\section{Knowledge Production I (Mode I) Knowledge Production II (Mode II)}

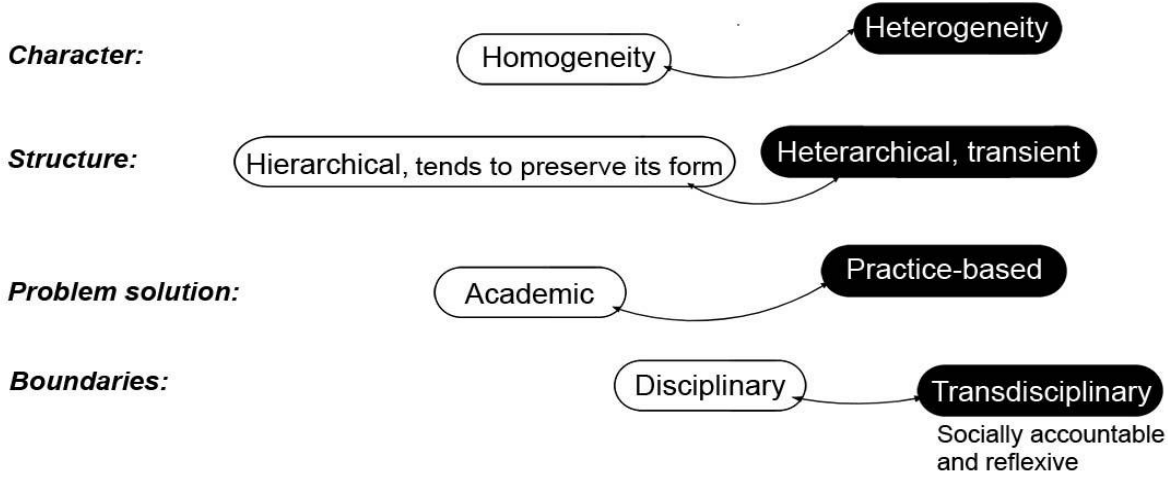

Figure 2: Differences between knowledge production modes I and II (Gibbons, et al. 1994, 3). 
epistemological axiom (complexity)." "The ontological axiom (Reality) is related to the different levels of reality and perception. "The logical axiom", also referred to as "the logic of the included middle"-a term derived from mathematics- is in-between and means a "passage from one level of Reality to another." "The epistemological axiom (complexity)" is "the structure of the totality of levels of Reality or perception is a complex structure: every level is what it is because all the levels exist at the same time" (Nicolescu 2006, 146).

In defining the level of reality, Nicolescu notes that the laws of quantum physics correspond to a new level of reality in total discontinuity with the laws of nature we know on our own scale, where Newtonian physics is valid. "Ontological" is an axiom regarding "being of the world, and being of ourselves, of the observer, and of the Object-being of the Subject, being of the Object and being of reality" (Volckmann and Nicolescu 2007, 80). The principle of superposition is that an object can exist in two different states. For the included middle logic, Nicolescu provides an example of paradoxes in which two different levels of reality exist at the same time, such as saying 'yes' and 'no' simultaneously. For the third axiom, complexity is understood as the structural connection of every level of reality to all other levels of reality (Nicolescu 2006, $147,151)$. These levels are not like Hegelian order but are fused with one another to form knowledge that engages practice and theory. These three axioms derive from their experimental evidence or has a source in quantum physics and the third axiom is related to other exact and human sciences (Nicolescu, 2006, 146).

In this approach, paradoxical thinking and different realities coexist. This methodology has been used for developing different approaches and perspectives in architecture in cases where a "societally relevant problem field is uncertain, when the concrete nature of problems is disputed, and when there is a great deal at stake for those concerned by problems and involved in dealing with them" (Schneider 2011, 98).

Transdisciplinary methodology occurs when different actors and participatory agencies take role not in a simultaneous way. In this context, transdisciplinary methodology emerges when these axioms and levels intersect simultaneously, with no defined beginning, and no end, therefore it is a complex and arbitrary progress. Moreover, transdisciplinary also helps "enable the cross-fertilisation of ideas and knowledge from different contributors that leads to an enlarged vision of a subject, as well as new explanatory theories" (Lawrance 2004, 489).

Since experts share roles in this methodology, transdisciplinary research can be beneficial in transgressing "institutional boundaries" and "finding a transparent way of dealing with uncertainties..." (Pohl and Hirsch Hadorn 2007, 37). From Nicolescu's ideas on transdisciplinarity, we can assume that this methodology offers an alternative to top-down research, where the researcher approaches the other with a predetermined perception, that instead helps bring the researcher and the research object into a new level of engagement.

When applied in architecture, this methodology enables architects and nonarchitects to deal with complex design problems, participatory design approaches, everyday practices, and sustainability, as well as urban housing through "hybrid modes of inquiry" that "are part of the knowledge landscape" (Doucet and Janssens 2011, 4). For example, research realised by GIRBa (Groupe interdisciplinaire de recherche sur les banlieues/ The Interdisciplinary Research Group on Suburbs) in Canada aims to interweave "practice-based research" and "evidencebased design through collaborative processes, in order to identify strategies for countering urban sprawl and its negative consequences on sustainability" (Doucet and Janssens 2011, 6). The actors in this methodology such as "scientists, professionals and policy decision-makers, as well as to train urban planners, architects and social scientists" become "agents of change" through active collaboration (Després, Vachon, and Fortin 2011, 34). The research and applications of this group initially started with "the distinct production of interdisciplinary research, architectural and urban design schemes, and contractual applied research, to an integrated program of research and action where each type of knowledge nourishes each other in a truly transdisciplinary manner" (Doucet and Janssens 2011, 6).

Transdisciplinary methodology can be applied to architectural and complex urban problems to uncover tacit knowledge emerging in a design context, i.e., the perceptions of the users, dwellers, participants or multiple understandings of the perceived space; in qualitative research, such a methodology can help balance the distribution of power among multiple actors, creating a horizontal plateau and what Deleuze and Guattari call an "overthrow ontology" (Deleuze 
and Guattari 2004, 28). This methodology can enable and teach us how to read ambiguous environmental problems embedded within socio-economic and political issues in a holistic way, rather than approaching the design problem within the confines of the vertical and hierarchical patterns instituted by modernism. Within this context, this form of ontology may offer a different perspective for rethinking different hierarchies and understanding and defining complex urban networks in terms of creating or predicting urban strategies and housing in uncertain situations.

In understanding the dynamics and emerging fragments in both the articulation of the dweller to his/her housing environment and the principles, set by housing authorities in a globalised age, the levels of this methodology are evaluated as the ontological axiom, the epistemological axiom and the included middle. In this research, the ontological axiom is examined within the information gained through a literature review and quantitative and qualitative data. These data are evaluated within an open and non-hierarchical structure of lateral fragments, in which each has the same importance, instead of a vertical and hierarchical structure. The epistemological axiom, a complexity axiom, emerges in terms of a quantitative research method, featuring dialogues with architects, sociologists, dwellers living in the chosen areas, face-to-face and written interviews with corporate managers and experts, photographs and video recordings, in-depth interviews and public surveys and the development of a theoretical exemplar with the support of artworks in İstanbul, Vienna and Amsterdam. The transparent superpositioning of the layers of research methodology that coincide with the transdisciplinary approach is shown in Figure 3.

As shown in this figure, three levels of transdisciplinary approach is evaluated in the re-reading process as three fragments; speed, flexibility and experimentality superimposing and ontological axiom as the reality and data derived from observation and literature research of housing exemplars, an art project realised in İstanbul in order to test and confront the meaning of these pre-determined fragments as the included middle which becomes a transition in the fusion of ontological and the epistemological axiom. These levels which are embedded in the process of the approach and the included middle emerged near the end of the process. The process started with literature research, followed by an observation on site in these three cities and later evolved into a complex process of in-depth interviews, and an art project.
These steps were not realised as a step-by-step approach, but they supported each other simultaneously.

\section{UNDERSTANDING URBAN NARRATIVES in NAR- CITY, DONAU CITY and the EASTERN DOCKLANDS}

Narcity, Donau City and the Eastern Docklands housing areas are approached as exemplars and evaluated through the manifestations of their designers and an approach that places sensitivity to the perceptions of dwellers in these areas on a level with the researcher. Different interpretations of reality are evaluated through layers of social, economic and political issues in İstanbul, Vienna and Amsterdam. In Narcity, Donau City and the Eastern Docklands, we confront different socio-economic and political contexts that have their own embedded fragments with their own spatiality. Notwithstanding such differences, these housing areas are similar in their free-market approach and their turnover in policies and effects on urban space. Experienced through the dweller's perception, they display emerging fragments in their differentiating patterns, as observed in new urban topographies.

\subsection{Housing exemplars}

As shown in Figure 4, these housing areas differ in some ways; for example, although istanbul is five times larger than both Vienna and Amsterdam, it has a lower density than Vienna and a higher density than Amsterdam. İstanbul, however, has the highest number of households. The low-density ratio in İstanbul is due to its wide geographical area, including large nonurban areas. Its transportation network is irregular and complex, and integration with housing areas is low when compared to the other two cities. In contrast, Vienna has a lower percentage of households. There is a developed infrastructure and network that integrates and articulates peripheries within the city centre. In Amsterdam, the number of households is low. Therefore, the population density in İstanbul is inarguably the highest among the three case exemplars, which is also evident from the considerable differences in the total number of households in these cities (Figures 4, 5). 


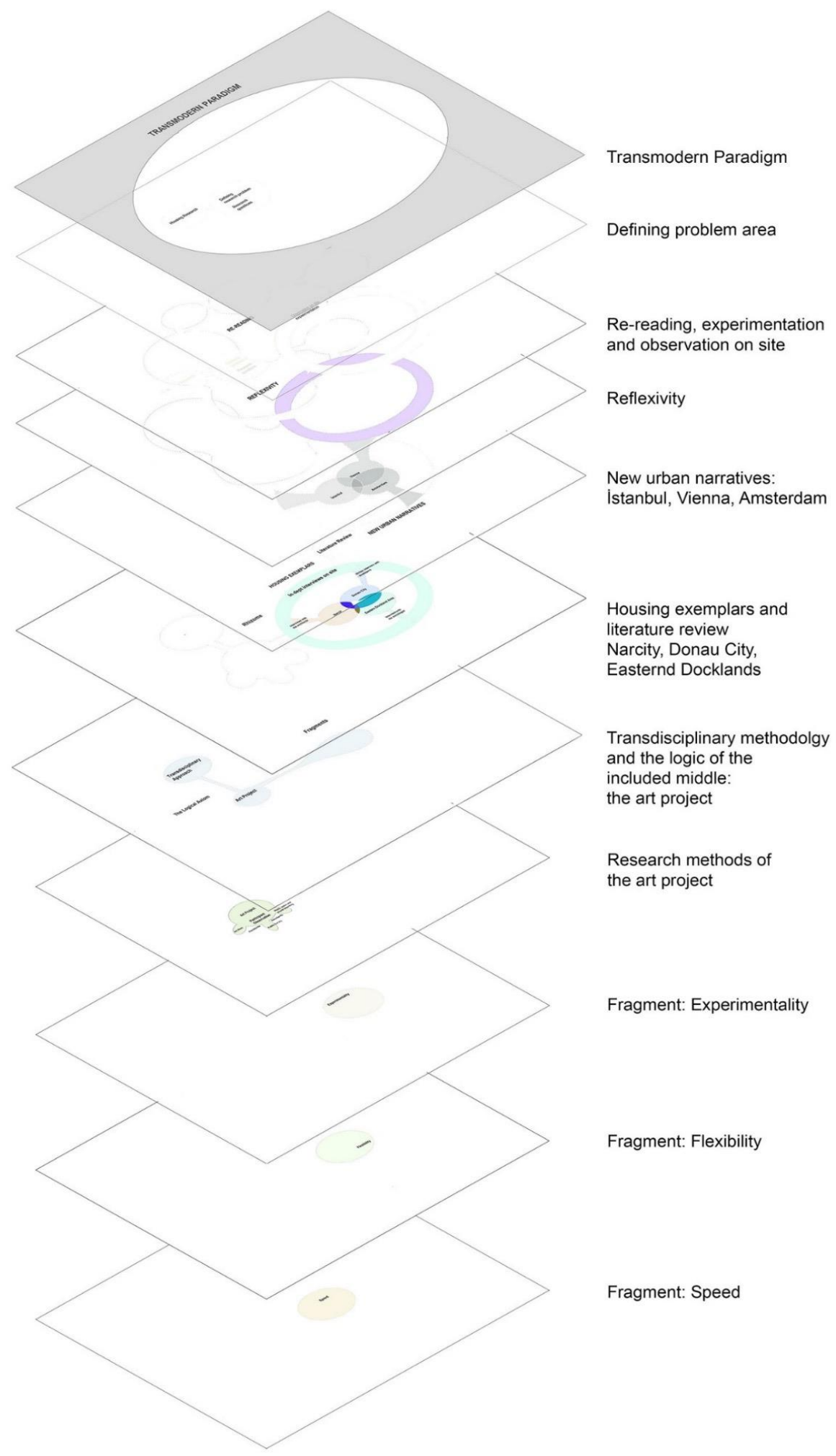

Figure 3: Superimposing fragments that emerged in the re-reading of Narcity, Donau City and the Eastern Docklands (Özdamar 2011). 


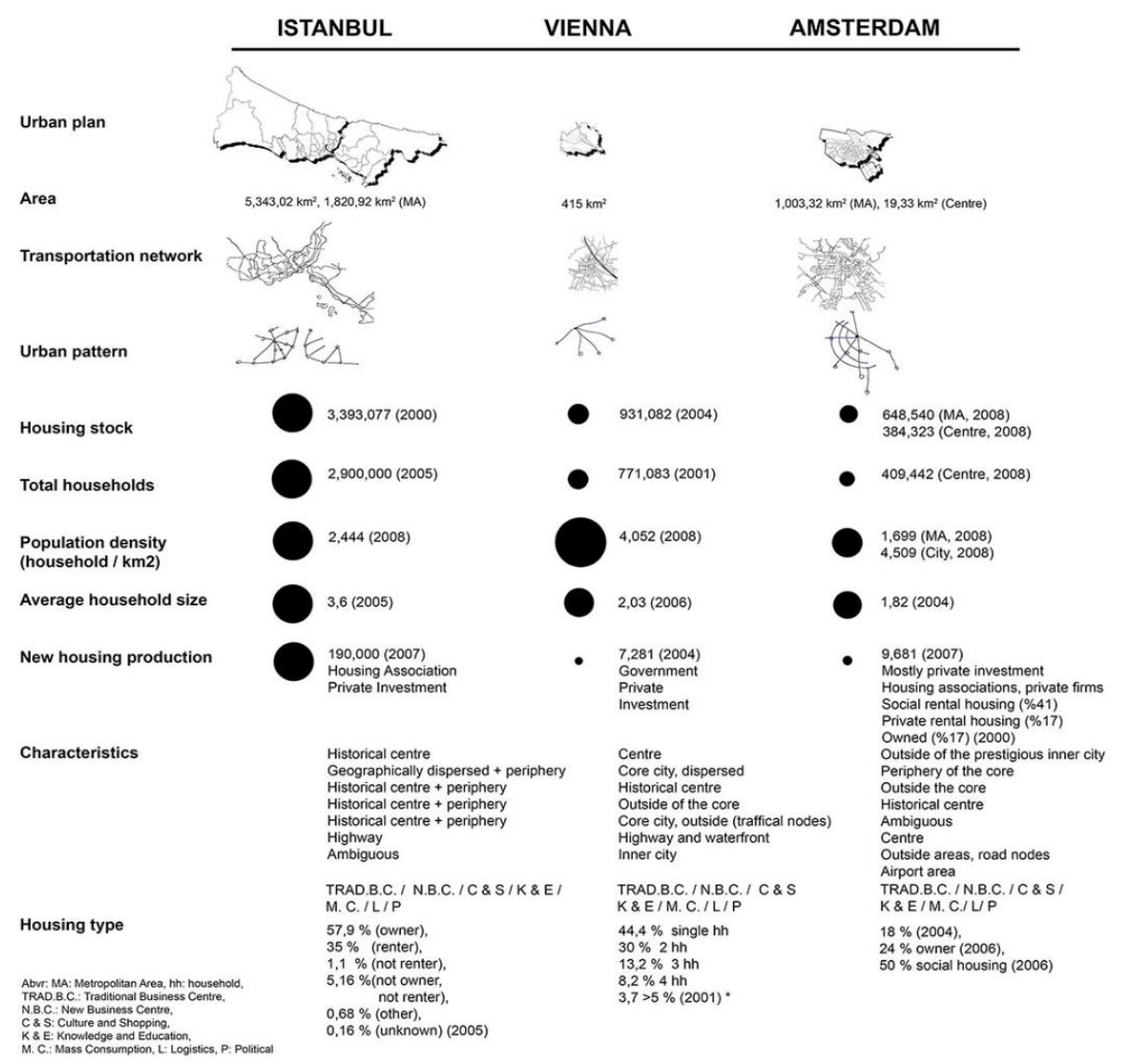

Figure 4: Housing and urban statistics for İstanbul, Vienna, and Amsterdam (TURKISH STATISTICAL INSTITUTE 2009; IMP 2010; GYODER 2010; Statistics Austria 2018; Wien.at 2009; Statistics Netherlands 2008; Amsterdam 2009; European Urban Knowledge Network 2009; Van Criekingen et al. 2004)

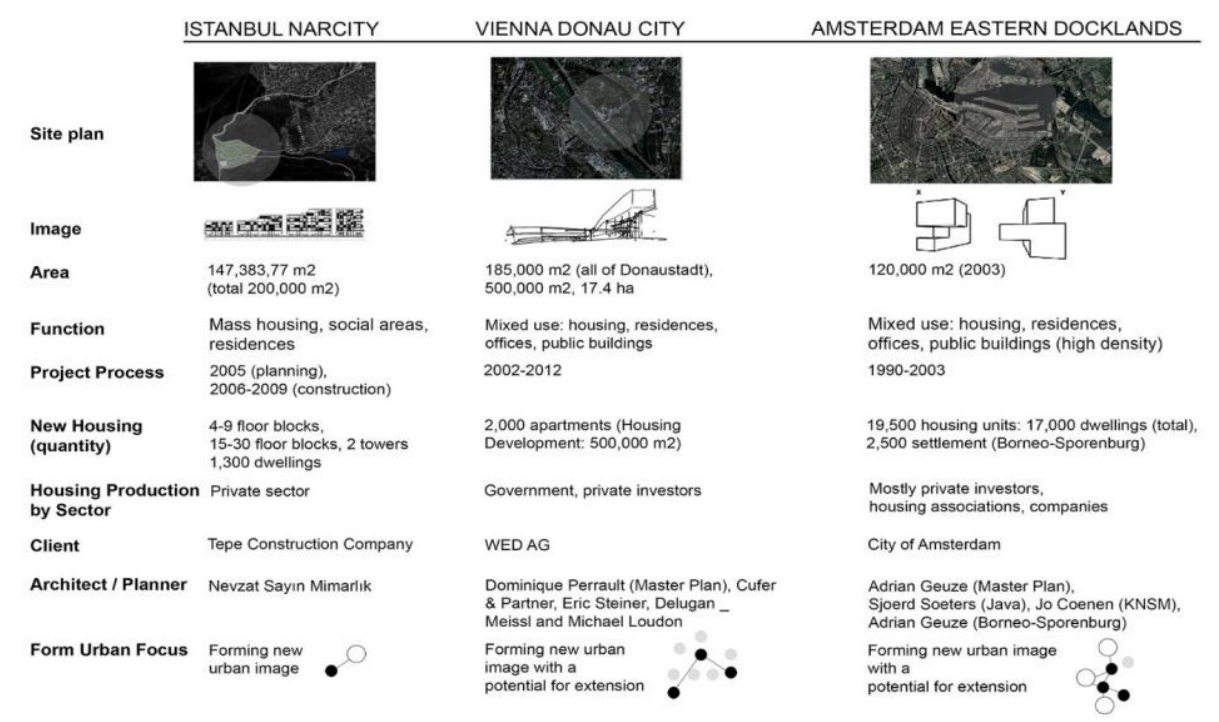

Figure 5: Characteristics of Narcity, Donau City and the Eastern Docklands (Google Earth 2009; Narcity 2009; ViennaDC, Donau City 2009; City of Amsterdam 2009; Trip 2007; Enichlmair and Borsdorf 2007; Coupland 1997; Anon 2009). 
The housing pattern in İstanbul is heterogeneous and involves rapid structural shifts. İstanbul is a city without roots, with overlapping, multi-centred, polyvalent forms of content and meaning - a city with different dimensions in motion, and, unlike trees and their root system, there is no centralized node. By virtue of istanbul's indeterminable urban nature, identifying a specific or planned pattern of urbanisation is not easy. Throughout the city's history, the genetic code of İstanbul has depended on its multi-centred character, with a polycentric growth and the simultaneous existence of different space-time relations in different parts of the city.

Narcity, a private residential area designed by Nevzat Sayın, is located in a district in Maltepe on existing infrastructure. The area is situated on a hillside whose plateau is occupied by a shantytown with irregular streets and buildings on top of one another. The housing blocks are spread around a linear axis corresponding to a previously planned distribution of services in the area, although the infrastructure is not properly distributed. Non-hierarchical connections can be found more prevalently in the self-organised fabric near the Başıbüyük neighbourhood. When approaching from the lower level, passing through the gecekondu area, one confronts an image of borderless modernist white blocks with façades in a variety of playful colours and green terraces laid over the hill. However, there is a difference in the narrative of
Narcity, which attempts to break the area's gatedness and leaves its doors open to the gecekondu area, with "relatively softer" security or walls towering over the area than those of new housing projects. According to Sayın, the placement and use of garages below apartments, the corridors connecting flats, the sign infrastructure and the social housing system are also new to İstanbul (Sayın 2009). Narcity, as mid-density housing, is a small-scale attempt by housing authorities to transform the consumption-oriented approach into social housing, which is not widely observed, though attracting a homogeneous economic household profile to dwell in the area (Figure 6). In this way, Narcity creates a node or breaking point that has the potential to trigger a new formation.

In contrast to Narcity, Donau City in Vienna is located near a corporate area, which is home to EU offices, on the left bank of the Danube. Once a remainder of blank urban space, Donau City housing is a businessand corporate-related residential area with a master plan by Dominique Perrault, based on the zoning criteria developed by Adolf Krischanitz and Heinz Neumann's open green space and grid pattern blocks, with a complex communication system and strict gridpattern blocks (Förster 2007, 19). The zoning and development plan was based on a design by Hans Hollein and Coop Himmelb(I)au. Krischanitz and Neumann drew up a conceptually innovative master plan: the distribution of public spaces and the development

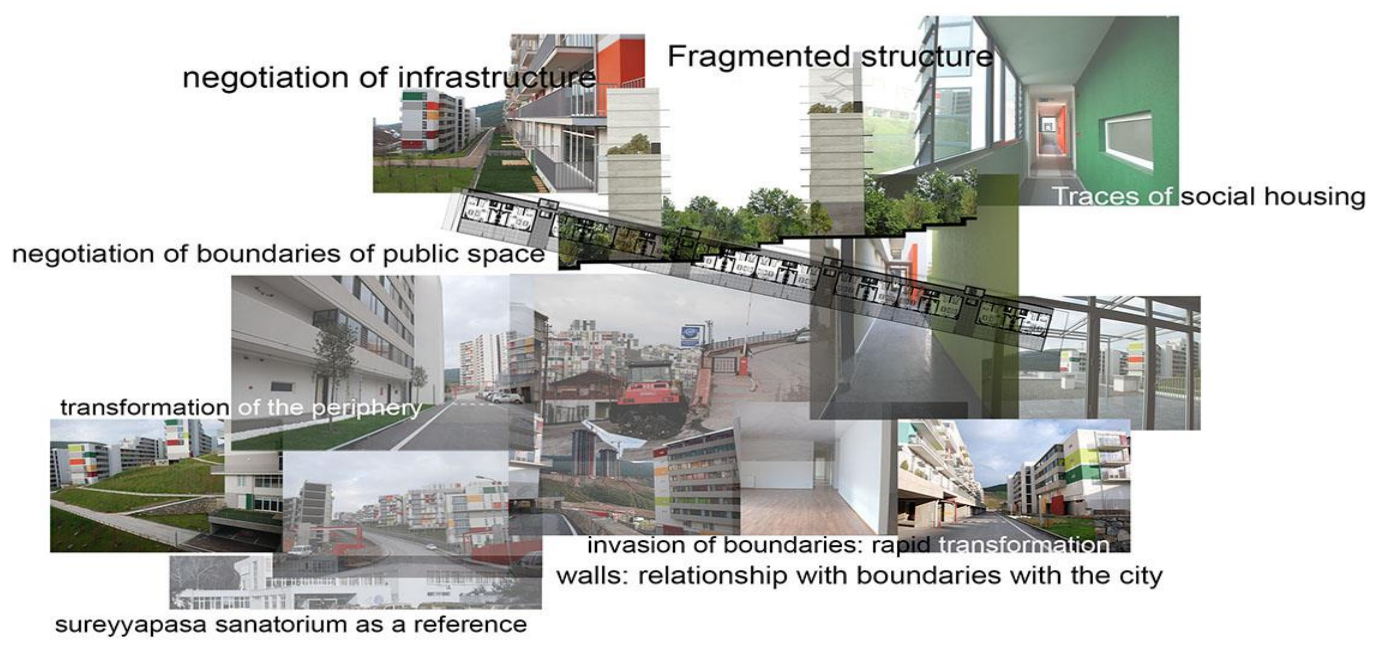

Figure 6: Emerging concepts in Narcity (Özdamar 2011; Sayın 2009). 


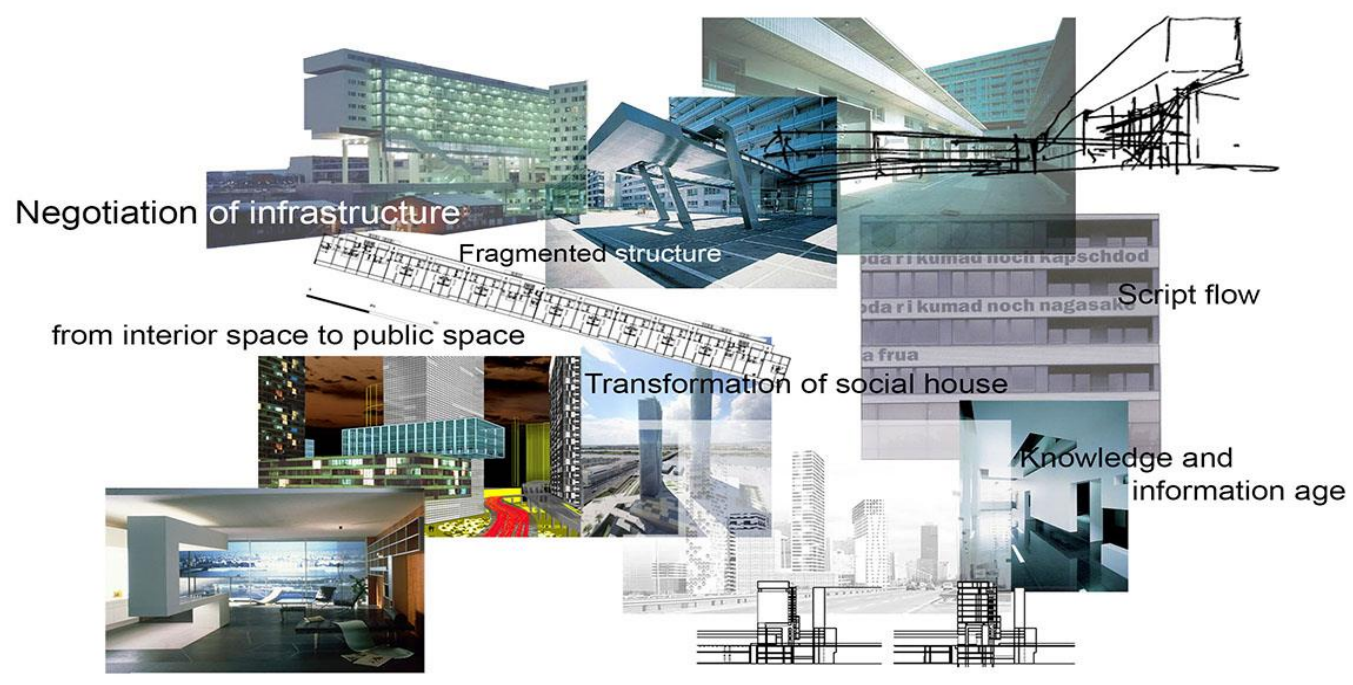

Figure 7: Emerging concepts in Donau City (Donau-City 1999; Delugan_Meissl 2010; ViennaDC, Donau City 2009; Delugan Meissl Associated Architects 2010; Donaucity 2010; Dominique Perrault Architecture 2009).

takes place at different levels and infrastructural facilities are present under this main level. The UNOCity and Donau City housing areas have become a major urban project and a new peripheral expansion of the city centre as a multifunctional district on the left bank of the Danube. The area "plays the role [of] a second centre of Vienna" (Donau City 2010), comprising functionally and socially mixed urban housing based on public-private partnerships (Figure 7).

Housing policies in Donau City aim to connect the area to urban life and develop it within a networked underground infrastructure, transforming former garbage areas into everyday living spaces. The different localities have emerged since the avantgarde movement in the 1920s and the fall of the Iron Curtain. However, the urban pattern, an underground transportation network, is articulated as a potential node point. Experimentality is considered a tool for improving urban quality in theme-oriented real estate (Förster 2007). In this network, experimentality emerges as a strategic tool with the flexibility and articulation to affect additional parts of the city through a complex underground network.

In the Eastern Docklands housing in Amsterdam, the articulation of the dweller was a prominent connective issue in the planning of the waterfront industrial pier along the IJ river into a residential neighbourhood. The design of the area is based on the Housing Atlas (Oostenbrink et al. 1991), and housing blocks are designed as an interior play on modular housing. The area was designed through the collaboration of 33 different architects under the coordination of Adrian Geuze as an extension of Vinex policies and a turn in "policies towards a more market-oriented approach" in Dutch housing in the 1990s; it focused on supplying a new housing agenda and decreasing the pressure on the city centre for the middle- and higher-income groups that had deserted the city in the 1980s (Van Der Vlist and Rietveld 2002, 11). Industrial peninsulas were transformed into residential neighbourhoods with private and luxury homes to prevent high-income groups from migrating from the city (Schaap 2003, 49-53).

The industrial area was transformed into a high-density residential area in 2003, and more than 8,000 dwellings were transformed from hangars into housing units, owner-occupied accommodations and apartment buildings (Karsten 2003, 297). Recalling the ring-shaped traditional city centre's rhizomatic pattern, which is formed by different canals creating different living areas, the new peripheral waterfront development appears to recall the historically unexpected and undetermined pattern, primarily through its experimental interior design, the variability in its 


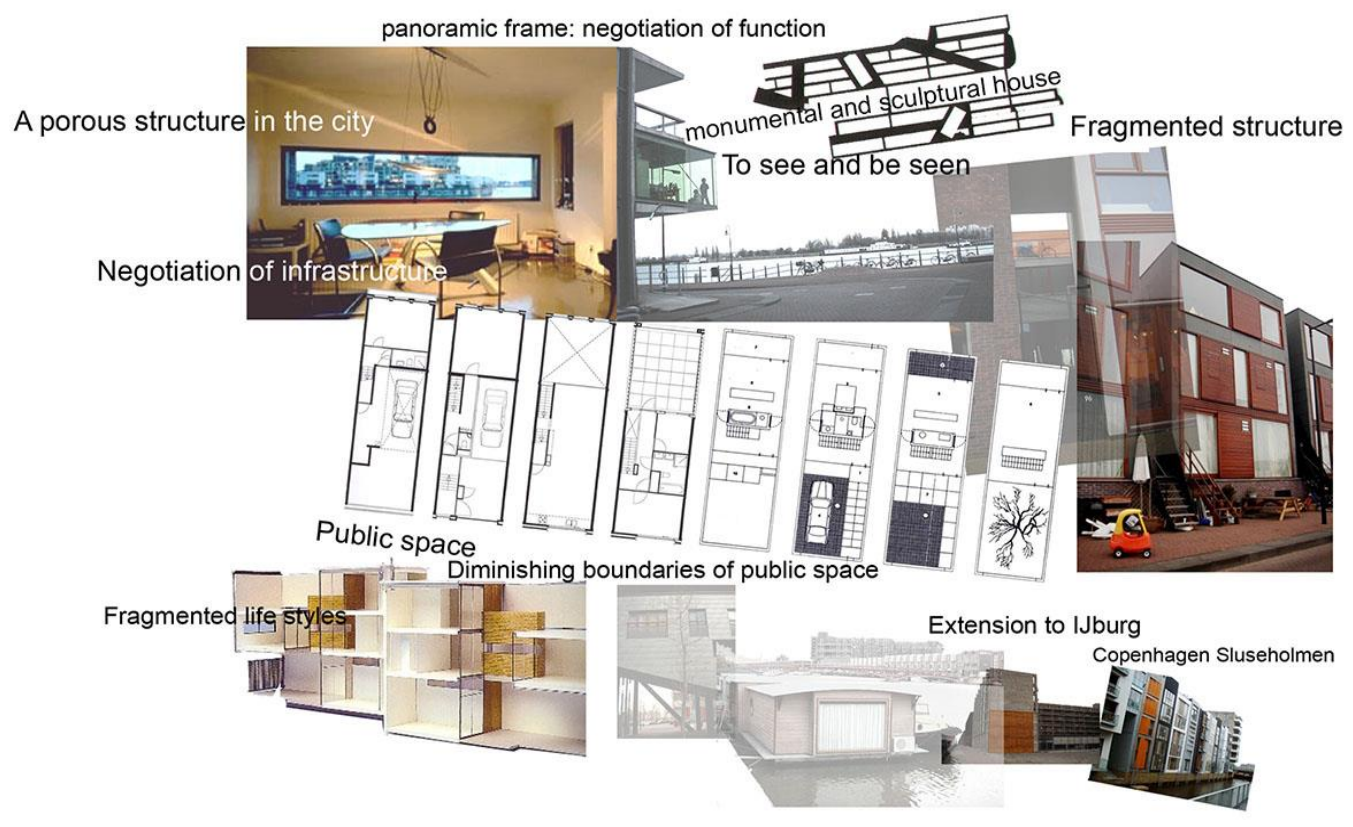

Figure 8: Emerging concepts in the Eastern Docklands housing (Karsten 2003, 297; Özdamar 2008; Abrahamse et al. 2003).

programme and function and its socially mixed nature. This mixture is accomplished by the interplay of space in the ground-floor rooms, such as spaces embedded within one another, a sort of fragmented interior organisation. This interior design is, in a sense, experimental and is also an approach to the city's density problem (Figure 8).

In mass housing, the density determines the patterns for housing production. In medium-scale residential areas, such as the chosen exemplars in this research with up to 100 dwellings per hectare, a softer, more experimental approach can be developed. In this network situation, a house becomes a triggering node in a network of local and global relationships. A contemporary house becomes both an articulation and extension of the urban narrative regarding socio-economic and cultural patterns and political identities. Between extension and articulation, urban housing gains new meanings.

The Eastern Docklands housing area is imageless and does not depict itself as urban housing. Instead, this area comprises a fragment or group of embedded urban fragments that the housing area signifies. The area is mixed-use with dwellings, home offices, social areas and passages between the houses, and the harbour offers a surface for floating boat houses, which are regarded as green Dutch housing. Although the area is part of a dominant housing policy, such as Vinex, rather than solely depicting the strict rules of the designed policies, it forms a moving context; a flexible strategy emerges from tradition to the new approach. In this sense, the Eastern Docklands area can be evaluated as an imageless identity on the periphery. The periphery is partially connected to the city centre through a cultural centre, working areas and the material shops below the apartments.

These exemplars depict a portrayal of contemporary housing in terms of different social, economic and environmental aspects. The housing market of İstanbul is the most important indicator of its citizens' social aspirations, Vienna is freed slightly from its restrictive policies for business and living, and Amsterdam is transforming society with an interplay and experimental acts in urban memory at different accelerations (Figure 9). This approach is different from the patterns in housing in istanbul. In these comparisons, Narcity is perceived as a relatively small area due to its steep topography. Donau City and the Eastern Docklands are perceived as more fragmented islands of houses with the potential to extend to the city in 

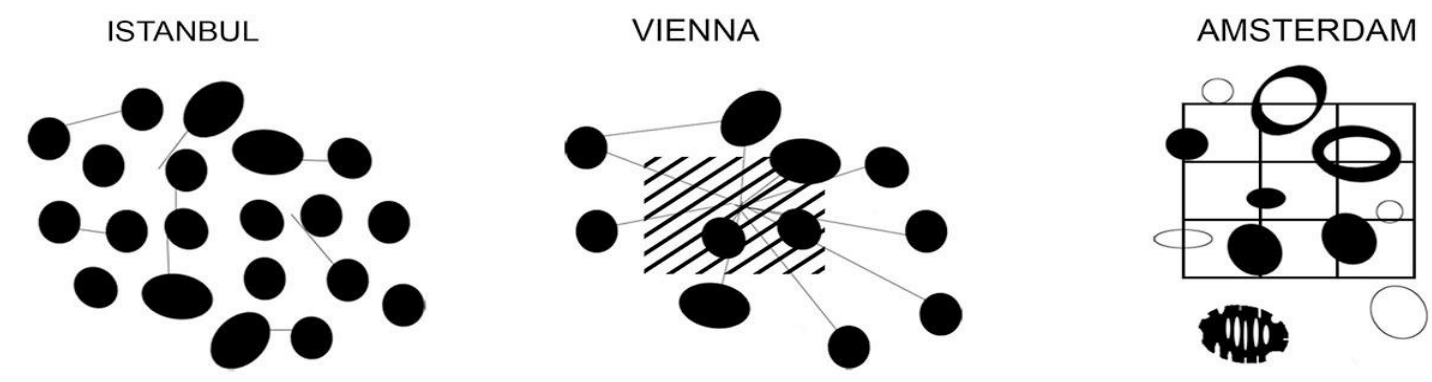

Figure 9: Emerging housing patterns observed in İstanbul, Vienna and Amsterdam (Özdamar 2011).

an endless repetition, becoming more like successful urban models.

Housing production is expected to provide sufficient housing to satisfy quantitative demand. This situation requires an evaluation of existing housing stock and renovation in the cities mentioned. In Vienna, there is a well-developed transportation network with housing extending to the periphery. The social rentalhouse production sector is in the foreground in Vienna and Amsterdam due to the rise in private investors. The government's parallel approach to both social housing and private development takes place on a rational and pragmatic grid, which triggers diversity and variety in the housing typology.

\subsection{Weaving the ontological and epistemological ax-} iom: Experimental art project as the included middle

Among these exemplars, the main problem of housing can be taken as the problem of the dweller's articulation to the built environment. Articulation is the integration of a dweller into his/her environment. When the city becomes dominated by a single-sided approach, the real actors are disregarded, and articulation is eliminated. Articulation refers to an engagement of the housing area with its environment or following global tendencies. Although all three exemplars narrate their autonomous character, they have a similar pattern.

In the Eastern Docklands housing, despite the strict rules for planning residential areas, a more experimental approach has led to a soft articulation of new housing areas to the city centre and other localities in which the residential areas form. Articulation may be intended by housing authorities and may transform the image of housing, creating consumption value; in some cases, articulation can be self-organised, as in the planning of the Eastern Docklands housing. Similarly, extension is a more self-organising construction/form when the residential area is undertaken as an initial force in creating extensions of a structure or a continuing form in the city, observed mainly in rapidly developing and globalising cities such as İstanbul. In İstanbul, the rapid production of housing has begun forming and orienting the remainder of the city by alienating itself and other spaces, such as shopping centres, with public space a leftover consideration.

Therefore, regarding the differences and diversities in the chosen exemplars, how can a dweller re-read the meaning of the house when there is a dominant form of meaning underlined by housing institutions, agencies, and policies? To undermine this, a methodology that approaches these phenomena from different levels of perception must be developed, in which the researcher is not the only centre and subject of the research. We confront these meanings with Clandinin and Connelly's "three-dimensional narrative inquiry space" (Clandinin and Connelly 2000, 63).

In this context, the logical axiom (logic of the included middle) is examined in terms of an experimental artwork, realised in İstanbul, that creates linkage by providing knowledge simultaneously within other levels and forming a connection between diversity and the similarities of an in-between condition. The work aimed to understand the role of housing institutions and perceptions of housing in a district in İstanbul and necessarily involved public participation. In order to find a relationship between emerging fragments derived from literature research and the perception of dwellers and to overcome the centralisation of the researcher, face-to-face interviews were held with participants in Sefaköy, a county in İstanbul. Two symbolic houses of $9 \mathrm{~m}^{2}$, made of iron supports and covered with canvas were installed for 15 days on a land 
rented in a randomly selected district in Sefaköy in istanbul. These two urban installations could be entered anytime but contained nothing within the but facades. They provided a starting point for the participants or observers in the project area to express their ideas, feelings about housing and home in the city. Interviews were conducted with a group of 15 participants over a period of 15 days. Two participant groups were determined in the district, and in-depth interviews were conducted with these participants. The first group of participants comprised 15 randomly selected households who were living in the district and were interested in housing. Semi-structured questionnaires, dialogues and interviews were conducted with this group. Questions about housing preferences, likes and dislikes, approaches to lifestyles and preferences related to their socio-economic status were recorded, and then a short film was made afterward.

The second group of participants consisted of ten students from the primary school next to the area. A painting workshop was held with these students, in order to comprehend their perception of contemporary housing in the city was observed. Later, volunteer students were interviewed on site and asked to draw their ideal images of the house facades. Interviews were conducted, asking questions about their images. In these paintings, students were asked to design a house or a collective house in the settlements, and their comments on the conceptual contexts of the house were examined according to their painted images, which were also recorded as photos and videos. For the majority of the participating student group, housing has been considered as a place with different physical and mental layers as a reflection of urban life.

After interviews and debates with all participants, speed fragments, such as production, consumption, image making, experimentalism and flexibility fragments, emerge as a visible strategy. The fragment relationships have an in-between nature. Through the observed housing areas, which signify from a general and global to a particular and local condition, fragments such as speed, experimentalism and flexibility become the ontological concerns of the urban dweller and housing in the contemporary era. These fragments are evaluated as topography/surface.

Speed as an initiating fragment of urban housing determines relations between capital and production. Speed-construction, speed-consumption and other consumable sides of housing are determinative factors in shaping the built environment. Speed shapes the form of the organisation and creates different localities with different relative transformative dynamics within a single city. Speed is defined as affecting the achievement of movements, such as politics, technology, the experience of cities, and the mobility of living environments, with different accelerations and relations with the transportation network. It is scrutinised in terms of housing approaches through changes-in the fragmented heterogeneous structures that have been engendered in İstanbul and in the context of articulation to global networks in Vienna and Amsterdam.

The experiment emerges as an attempt to incorporate a certain discourse into diversity and variety as a strategy in housing politics and in the formation of housing areas. Flexibility, as stretching urban structures, has emerged as an articulation process within the scope of an open structure related to sustainability. Deriving from the patterns of housing exemplars that have been discussed, speed, experimentalism and flexibility fragments emerge as "new transformative factors" in the contemporary housing narrative and for future housing areas (Özdamar, 2013, 153160).

These fragmented topographies, with their different effects on social, economic and political patterns in the chosen cities, evince a need for re-reading. The cities have become spaces of diversity, variability and ambiguity. In this context, we cannot understand them through a single-directional approach that analyses only one part of the city. Instead, we must determine the three-dimensional, rhizomatic, singular yet global pattern that transforms them all.

\section{3. "Three-dimensional narrative inquiry space" in a transdisciplinary approach to housing}

In the context of levels of transdisciplinarity, Narcity, Donau City and the Eastern Docklands housing areas are approached through layers that transect and stimulate one another and consist of interrogating the validity of the fragments in different scales and multiple realities. Through the observed housing areas' extension from a particular and local condition to the general and global, we estimate that speed, experimentality and flexibility fragments, among others, are the ontological concerns of urban housing today. 
The three axioms are approached and evaluated as a topography/surface, cross-cutting one another. The topography/surface term provided the ability to evaluate the fragments of the discussed exemplars in interaction with other housing areas and other units of the city through a wide, global perspective. However, as characteristic of transdisciplinary methodology, the layers emerged clearly after the entire process was completed.

In contrast to a quantitative research method, this methodology is unplanned before the research problem arises, and it arises from patterns that emerge during the process of re-reading the phenomena under study. The methodology can be summarised as extending beyond definition to the production of cross-re-readings and the development of networks of both objective and subjective information. The subjective and objective experience and narrative fuse to gain new meaning.

This "three-dimensional narrative inquiry space" offers a spatiality within which time and space, as well as the observer or the researcher who reads/evaluates the narrative, change dynamically. With modernism, the fragmentation of the relationship between architectural space and time and the urban patterns bring a mindset that examines urban space as a fragmented entity. It is possible to grasp life as a whole when the narrative space is a whole in which the layers melt together and hybridise. Otherwise, the layers will remain forcibly attached or associated in the designer's eyes, causing the design to become stereotypical. In this context, if we lay aside what we call narrative, we should consider this three-dimensional narrative space to grasp the unity of life and spaces with a more immanent eye.

So, what kind of a relationship is there between the concept that makes cities dynamic and the space of three-dimensional narrative inquiry? Here, the threedimensional narrative space of inquiry can be beneficial, not as a design problem that can be solved with precise horizontal or vertical hierarchies or conceptually polarised dichotomies, but in terms of articulating complex relationship networks towards grasping or comprehending possible meanings and discovering tacit knowledge. On the axis of overlapping user-perceiver and housing policies, the many diverse layers emerging from a research problem should be treated as an open-ended statement in terms of the ability to develop a new perspective, not merely to come to a solution.

As referenced in figure 3, taxonomic expressions or descriptions take place as independent layers in the context of reading the house or city and are independent topographies that the researcher tries to associate, in his or her own way, to reach a result. However, such layers are far from a linear form of information, all aspects of which can be instantly discovered. In this context, trying to establish a relationship between these three different housing areas, whose socio-economic and political approaches are quite different, and the perceiver requires addressing these differences while preserving rather than homogenising them. This requirement also runs counter to the hierarchical gaze towards space, which irreversibly "flattens" the space-time relationship in today's global world. It is not easy to satisfy all the needs of the user or the buyer in this fast age of increased mobility. Here, creating an interface that can confront the expectations of some users with those of others can create good spatial quality, comfort and a sense of belonging to the home, the neighbourhood and the city.

\section{FURTHER DISCUSSION: TOWARDS TRANSDISCIPLI- NARY RESEARCH in ARCHITECTURE}

This study approaches transdisciplinary methodology in architecture by re-reading selected exemplars as capable of producing new knowledge and triggering new forms of housing. In understanding contemporary urban housing, the potentialities of different approaches are determined through re-reading housing areas in Narcity, Donau City and the Eastern Docklands using a layered approach that includes both the objective and subjective levels. Speed, experimentality and flexibility are observed as fragments that trigger and transform urban housing in the selected cities. These fragments are interconnected and transform urban patterns from a monocentric condition to polycentric expansion that depends on diversity. This dynamic view crosses disciplines to understand their boundaries while also engaging architecture, art, sociology and politics. The transdisciplinary approach raises questions regarding the lateral hierarchies and power observed in many cities rather than the vertical hierarchies and top-down planning strategies that have shaped cities for many centuries. 
This methodology can help transcend the definitions of the existing user/participant-architect dichotomy through linking theory and practice. Regarding the difficulties in its application and in engaging theory and practice, the methodology is evaluated through its ambiguity. The researcher must amalgamate the changing nature of the environment and the phenomena when engaging housing with urban policies. The strategy of this methodology is established based on the nature of the problem and is undertaken for the dynamic spatio-temporality offered by this research and experimentation process. This methodology can also be related to an imageless theory, rendering the invisible visible, which can help reveal the nature and underlying structures of rhizomatic cities.

However, this model is not efficient in every context. The difficulty of this approach lies in its transient and ambiguous process, as the design of the methodology emerges at the end of the process. Challenges may also arise during the framing of the problem area. In urban housing and related issues, this methodology can help transgress the boundaries among fixed forms of policies, management, and production and bridge fact and fiction in the re-reading and mapping of controversies among researchers, designers and scholars in related disciplines at different levels of comprehension.

\section{Acknowledgements}

This article depends on the Ph.D. thesis by the author supervised by Prof. Dr. Semra Aydınlı at Istanbul Technical University. This work was supported by the [Istanbul Technical University Scientific Research Project (2008-2011) supervised by Prof. Dr. Semra Aydınlı] under Grant [number 32358]; [Funding Agency Istanbul Metropolitan Municipality, Istanbul 2010 Capital of Culture Visual Arts Directorate], [Funding Agency Fabrikart] and [Funding Agency Hakteks].

\section{References}

Abrahamse, Jaap Evert, Marlies Buurman, Bernard Hulsman, Hans Ibelings, Allard Jolles, Ed Melet, and Ton Schaap, eds. 2003. Eastern Harbour District Amsterdam, Urbanism and Architecture. Rotterdam: Nai Publishers.

Anon. 1999. Image from Java Island.
City of Amsterdam. 2009. "Gemeente Amsterdam." Accessed June 11, 2011. http://amsterdam.nl/.

Clandinin, D. Jean and F. Michael Connelly. 2000. Narrative Inquiry: Experience and Story in Qualitative Research. San Francisco: Jossey-Bass Publishers.

Coupland, Andy, ed. 1997. Reclaiming the City, Mixed Use Development. London: E \& FN Spon Press.

Deleuze, Gilles and Felix Guattari. 2004. A Thousand Plateaus: Capitalism and Schizophrenia. London: Continuum.

Delugan_Meissl Associated Architects. 2010. Accessed May 1, 2010. https://www.dmaa.at/projekte/.

Delugan_Meissl, State of Flux, Architekten Wien. 2010. Accessed May 13, 2010.

http://www.aoeg.net/state-of-flux/texteD_flux.pdf.

Després, Carole, Geneviève Vachon and Andrée Fortin. 2011. "Implementing Transdisciplinarity: Architecture and Urban Planning at Work." In Transdisciplinary Knowledge Production in Architecture and Urbanism Towards Hybrid Modes of Inquiry, edited by Isabelle Doucet and Nel Jassens, 33-49. Urban and Landscape Perspectives 98. Dordrecht: Springer. https://doi.org/10.1007/978-94-007-0104-5_3

Dominique Perrault Architecture. 2019. Accessed April 12, 2019. http://www. perraultarchitecte.com/indexuk.htm>.

Donau-City. 1999. Accessed May 12, 2010. http://www.nextroom.at/building.php?id=2559\&inc=home.

Donau City. 2010. Accessed May 12, 2010. https://www.wien.gv.at/stadtentwicklung/studien/pdf/b008127.pdf.

Doucet, Isabelle and Nel Janssens, eds. 2011. Transdisciplinary Knowledge Production in Architecture and Urbanism Towards Hybrid Modes of Inquiry. Urban and Landscape Perspectives, 11 (X). Dordrecht: Springer. https://doi.org/10.1007/978-94-007-01045

Enichlmair, Christina and Axel Bordsorf. 2007. "Vienna Erberger Mais: Public-Sector driven long-term planning strategies." In Framing Strategic Urban Projects: Learning from Current Experiences in European Urban Regions, edited by Willem Salet, Enrico Gualini, 223-246. New York: Routledge. 
https://www.uibk.ac.at/geographie/personal/borsdorf/pdfs/lv.pdf. https://doi.org/10.1111/j.14682427.2008.00817_3.x

European Urban Knowledge Network. 2009. Accessed April 22, 2009. http://www.eukn.org/eukn/.

Förster, Wolfgang. 2007. 80 Years of Social Housing in Vienna. Accessed April 18, 2007.

http://www.wien.gv.at/english/housing/promotion/rtf/socialhous.rtf.

Gibbons, Michael, Camille Limoges, Helga Nowotny, Simon Schwartzman, Peter Scott and Matin A. Trow. 1994. The New Production of Knowledge: The Dynamics of Science and Research in Contemporary Societies. California: Sage Publications.

https://doi.org/10.1177/004839319702700304

Google Earth. 2009. Accessed May 10, 2009. https://www.google.com.tr/intl/tr/earth/.

GYODER. 2011. Accessed June 15, 2011. http://www.gyoder.org.tr/.

IMP (Istanbul Metropolitan Municipality). 2010. Accessed February 13, 2010. http://www.ibb.gov.tr/.

Karsten, Lia. 2003. "Viewpoints." Children's Geographies 1, no. 2, 295-298.

https://doi.org/10.1080/14733280302190.

Kuhn, Thomas. S. 1962. The Structure of Scientific Revolutions. Chicago: The University of Chicago Press.

Lawrance, Roderick, J. 2004. “Housing andhealth: from interdisciplinary principles to transdisciplinary research and practice." Futures, 36, 487-502. https://doi.org/10.1016/j.futures.2003.10.001.

Narcity. 2009. Accessed March 21, 2009. http://www.narcity.com.tr.

Nicolescu, Basarab. 2002. Manifesto of Transdisiplinarity. USA: Suny Press.

Nicolescu, Basarab. 2005. "Towards Transdisciplinary Education." TD: The Journal for Transdisciplinary Research in Southern Africa, 1, no. 1, 5-16. https://tdsa.net/index.php/td/article/view/300. https://doi.org/10.4102/td.v1i1.300.

Nicolescu, Basarab. 2006. "Transdisciplinarity-Past, Present and Future." In Moving Worldviews-reshaping Sciences, Policies and Practices for Endogenous
Sustainable Development, edited by Bertus Haverkort and Coen Reijntjes, 142-166. Accessed March 21, 2009. COMPAS Editions. http://www.compasnet.org/blog/wp-content/uploads/2011/03/movingworldviews/movingworldviews.pdf.

Nicolescu, Basarab. 2008. "Transdisciplinarity-History, Methodology, Hermeneutics." Economy Transdisciplinarity Cognition, $\mathrm{XI}$, no. 2, 13-23. http://www.ugb.ro/etc/etc2008no2/ks1\%20(2).pdf.

Novak, Marcos. 1998. "Transarchitectures and Hypersurfaces, Operations of Transmodernity." Architectural Design, Hypersurface Architecture, 68, no. 5/6, 85-89.

Oostenbrink, Marinus, Bouw- en Woningdienst Amsterdam, Afdeling Produktontwikkeling, et al. 1991.

Een woonatlas voor Amsterdam: woonconcepten voor de jaren '90 (Woonatlas Amsterdam, Living concepts for the 90s). Amsterdam: Bouw- en Woningdienst, Afdeling Produktontwikkeling (Amsterdam Construction and Housing Service) https://doi.org/10.1163/2214-8264_dutchpamphlets-kb2-kb24473

Özdamar, Esen Gökçe. 2011. "A Re-reading of Narrative of Contemporary Housing In Context of Urban Dynamics: Istanbul, Vienna, Amsterdam." (Unpublished PhD diss., Istanbul Technical University, Architectural Design Programme.

Özdamar, Esen Gökçe. 2013. "Breaking from Plato's cave: Towards a holistic approach in urban housing in İstanbul." Arquitetura Revista, 9, no. 2, 153-160. https://doi.org/10.4013/arq.2013.92.08.

Özdamar. Esen Gökçe. 2008. Personal archive.

Pohl, Christian and Gertrude Hirsch Hadorn. 2007. Principles for Designing Transdisciplinary Research. (Translated by Anne B. Zimmermann). Swiss Academies of Arts and Sciences, München: Oekom Verlag $\mathrm{GmbH}$.

Sayın, Nevzat. 2009. Interview, İstanbul, July 28, 2009.

Schaap, Ton. 2003. "Found object: The Urban Planning of the Eastern Harbour District." In Eastern Harbour District Amsterdam, Urbanism and Architecture, edited by Jaap Evert Abrahamse, Marlies. Buurman, Bernard Hulsman, Hans Ibelings, Allard Jolles, Ed 
Melet and Ton Schaap, 49-53. Rotterdam: Nai Publishers.

Schneider, Tatiana. 2011. "Discard an Axiom." In Transdisciplinary Knowledge Production in Architecture and Urbanism Towards Hybrid Modes of Inquiry, edited by Isabelle Doucet and Nel Jassens, 97-115. Urban and Landscape Perspectives 98. Dordrecht: Springer. https://doi.org/10.1007/978-94-007-01045_7

Statistics Austria. 2018. Accessed April 03, 2018. http://www.statistik.at/.

Statistics Netherlands. 2008. Accessed March 24, 2008. http://statline.cbs.nl/StatWeb/publication/?DM=SLEN\&PA $=7413 E N G \&$ D1 $=0-3,6,11,16,22-$ $39,41,47-53 \& D 2=39,66,88,129 \& D 3=12,(I-2)-$ $I \& L A=E N \& V W=T$.

Trip, Jan Jacob. 2007. "What makes a city? Planning for "Quality of place": The case of high-speed train station area development." PhD diss., Delft University of Technology. http://repository.tudelft.nl/assets/uuid:a0ee18b2-8cf3-45f7-8e2b45141ab28ef4/otb_trip_20070320.pdf?origin=publication_detail.

TURKISH STATISTICAL INSTITUTE. 2019. Accessed April 06, 2019. http://www.tuik.gov.tr/PreTablo.do?tb_id=40\&tb_adi=Konut\%20\%DD statistikleri\&ust_id=11.

Van Criekingen, Mathieu, Christophe, Guisset, Valérie Biot, and Christian Vandermotten. 2004. Spatial Dynamics of Service Activities in European Metropolitan Areas: Lessons from the Comparison of the Comet Case Studies, Wp8 report part 2, Comet Brussel's Team, IGEAT - Université Libre de Bruxelles. Accessed June 17, 2011.

http://www.oeaw.ac.at/isr/comet/documents/Fi-

nal_Results/COMET_de-

liv_no09_WP8_part2\%20SPATIAL\%20DYNAM-

ICS\%200F\%20SERVICE\%20ACTIVITIES.pdf.

Van Der Vlist, Arno and Piet Rietveld. 2002. The Amsterdam Metropolitan Housing Market 2002-36. Research Memorandum, Faculty of Economics and Business. Ansterdam: Administration Vrije Universitei.

ViennaDC, Donau City. 2019. Accessed June 14, 2019. http://www.viennadc.at.
Volckmann, Russ and Basarab Nicolescu. 2007. Transdisciplinarity: Basarab Nicolescu Talks with Russ Volckmann. Integral Review, no. 14, 73-90. http://integral-review.org/transdisciplinaritybasarab-nicolescu-talks-with-russ-volckmann/.

Wien.at. 2009. Accessed June 22, 2009. http://www.wien.gv.at/english/politics/statistics/pdf/versorgung-e.pdf.

Amsterdam. 2009. Wikipedia, Accessed December 30, 2009. https://en.wikipedia.org/wiki/Amsterdam. 